\title{
Workplace Risk Prevention in Public Building Projects in Mexico
}

\author{
Rómel G. Solís-Carcaño*, José A. González-Fajardo, Enrique de J. Ayora-Sosa \\ College of Engineering, Autonomous University of Yucatan, Merida, Mexico \\ Email: ${ }^{*}$ tulich@correo.uady.mx
}

Received 22 August 2014; revised 25 September 2014; accepted 10 October 2014

Copyright (C) 2014 by authors and Scientific Research Publishing Inc.

This work is licensed under the Creative Commons Attribution International License (CC BY). http://creativecommons.org/licenses/by/4.0/

(c) (i) Open Access

\section{Abstract}

The importance of risk prevention in the workplace during the construction of public infrastructure projects is particularly relevant due to the large number of workers involved as well as the frequency and severity of the accidents. The aim of this work was to conduct an exploratory study of workplace risk prevention in the construction of public work projects in Mexico. The methodology was based on a case study which included an exploration of the attitudes assumed by the civil servants working for the government agency, regarding workplace risk prevention, and the observation of construction processes in a sampling of projects. The results show that the regulations are not fully adhered to during the stages of project planning and contracting for the work. During project designing, the inclusion of criteria regarding workplace risk prevention is relegated, and during public tendering, the experience of the contractor in risk prevention and workplace safety plans are not taken into account. Consequently, as one might expect from the above, during the construction processes, it was possible to observe that only about half of the prevention requirements applicable in the workplace were actually complied with.

\section{Keywords}

Prevention, Workplace Risks, Construction, Public Works, Supervision

\section{Introduction}

The execution of public works has great significance, quantitatively speaking, in the area of workplace risk prevention due to a diversity of factors, such as number of jobs offered, high accident rate, and frequency and severity of the accidents [1]. In this study, workplace risk prevention in construction will be referred to hereafter with the abbreviation prevention.

\footnotetext{
${ }^{*}$ Corresponding author.
} 
According to statistics in Mexico, the construction industry generates 5.6 million jobs and $6.7 \%$ of Gross Domestic Product [2]. From the point of view of the origin of investment, the fraction corresponding to public works represents approximately $65 \%$ of the total investment in the construction sector in this country [3].

With respect to the accident rate, according to statistics provided by the Secretariat of Labor and Social Security, in 2011, the group denominated Construction of Buildings and Civil Engineering Works registered an incidence rate of 3.85 per 100 workers in workplace accidents and occupational illnesses or diseases, while the rate for total economic activities was 2.85. Regarding the number of deaths, the incidence rate for the construction group in the same year was 2.21 per 10,000 workers, while the rate for total economic activities was 0.82 [4].

Construction projects are executed by groups of people, organized under the direction of a Project Manager, which must legally and morally accept the responsibility of providing safe and healthy conditions in the workplace. The best strategy to accomplish this is through prevention, where the objective is to achieve "an adequate work environment, with fair working conditions, where workers of both sexes can carry out an activity with dignity and where they can participate in the improvement of health and safety conditions" [5].

Safety in the workplace is a fundamental and inalienable right recognized by every judicial standard [6]-[8]. However, in reality, what every manager or director is willing to do in order to provide a safe environment for the workers depends mainly on his or her safety culture.

In order for prevention in the work site to become a reality, a concurrence of wills between three actors is essential: the owner of the building under construction (who will benefit from its use), the builder (who will profit from the construction of the building) and the government (who has the obligation to safeguard workers' rights) [9].

In the case of the construction of public works-in which the government plays two of the three roles previously mentioned - the concurrence of wills should be accomplished more easily; however, in general, no differences can be appreciated between the workplace environments of public works and private projects [10]. Similarly, in Spain, Rodríguez [1] points out that the legal framework regulating contracts for public works "does not put into effect any prevision to guarantee rights, such as the life and physical integrity of the workers involved in the construction of infrastructures". From this we can appreciate the importance of studying the execution of public works, from a preventive point of view.

The aim of this work, therefore, was to carry out an exploratory study of workplace risk prevention in the construction of public infrastructure projects in Mexico, by means of a case study.

\section{Methodology}

For reasons of confidentiality, any information referring to the case under study has been omitted in this paper. The government agency studied herein, in charge of the management of a type of public works, will be denominated hereafter as the institution. The study methodology included: an exploration of the attitudes assumed by members of the institution and the way in which this encourages prevention values; the examination of specific actions, relating to prevention, carried out by the people performing the principle activities in the institution; and finally, observation in the workplace of the execution of a sampling of projects managed by the institution.

The projects observed were constructions of social infrastructure with costs ranging from one to two million US dollars. Typical stages for the management of these projects are as follows: the institution carries out the planning and design stages; after budget authorization, the institution awards the works by means of public tendering and subsequent contracting. During the execution of the works, the institution carries out supervision and project control; once the construction is completed, the institution receives the works and hands them over to the user, who also works for another government institution.

\subsection{Attitudes Assumed by Members of the Institution and Encouraging Prevention Values}

Information was gathered from the following members of the institution: the head of department responsible for project design (hereafter denominated designer), the head of department responsible for tendering and contracting (hereafter denominated as adjudicator); and in the construction area, the head of department responsible for supervision and control, and 15 worksite supervisors (all of whom will be denominated hereafter as supervisors).

For this part of the study, a questionnaire comprising two sections was prepared; the aim of the first section was to ascertain the attitude assumed by members of the institution and in the second to determine what meas- 
ures are taken by the institution to encourage prevention values. This instrument was developed based on an analysis of the operations manual of the institution pertaining to the guidelines followed in public tenders for the works and the contract model used. As a whole, the instrument consisted of 33 items, presented in the form of affirmations; during its application, the participants were asked to express their position regarding each affirmation, by means of a Likert type scale which included 5 values: 1 (totally disagree), 2 (disagree), 3 (neutral: neither agree nor disagree), 4 (agree) and 5 (totally agree).

Each section of the questionnaire consisted of four components, which are shown in Table 1; in order to facilitate a better understanding of the content of the instrument, the same table also presents examples of the items in each component.

Analysis of the data obtained from the application of this instrument was performed by means of descriptive statistics: medians and interquartile range for each component, and for each function within the institution. This measure of central tendency was selected due to the fact that the data were ordinal.

\subsection{Specific Actions Carried Out by Members of the Institution}

In order to determine the specific actions relating to prevention carried out by the people involved in the three functions of the institution, another instrument elaborated with open questions was applied; this instrument was different for each of the three functions. The instrument included actions which, in accordance with the normative framework of the institution and that of the Secretariat of Labor and Social Security of Mexico (STPS), must be carried out on a regular basis in the institution. The number of questions for each function were as follows: the designer, 12 (example: Does the design department select the mechanisms of collective safety that must be employed throughout the construction of the project?); adjudicator, 7 (example: Are the constructors participating in the tendering process required to demonstrate their experience and technical capacity in relation to workplace risk prevention?); and the supervisors, 13 (example: When an accident occurs in the worksite, does the supervisor conduct an investigation to determine the causes?). Analysis of the data was mainly based on identifying habitual behaviors, and in some cases, on the calculation of proportions.

\subsection{Observation of Project Execution}

In order to observe the preventive actions being carried out in the worksite, 13 building projects were selected among those being executed during the development of this investigation. Seven of the projects were classified as small works (area smaller than $4000 \mathrm{ft}^{2}$ ) and 6 as medium-sized (area larger than $4000 \mathrm{ft}^{2}$ ), according to the criteria of area and height in the NOM-031-STPS-2011, Construction-Health and safety conditions in the workplace [11]. For the realization of the observations, an instrument was elaborated consisting of 376 items, and compliance was verified in the worksites. The content of this instrument was based on the Guide for the Evaluation of Compliance with the Normative Standards for Workplace Health and Safety, of the STPS [12].

Table 1. Parameters to measure respondents’ perception on risk prevention.

\begin{tabular}{|c|c|c|c|}
\hline \multicolumn{2}{|l|}{ Section 1} & \multicolumn{2}{|l|}{ Section 2} \\
\hline Attitude of members of the institution & $\begin{array}{l}\text { No. of } \\
\text { items }\end{array}$ & Encouraging values & $\begin{array}{l}\text { No. of } \\
\text { items }\end{array}$ \\
\hline $\begin{array}{l}\text { General aspects of prevention. } \\
\text { Example: "Workplace risks can always be avoided or mitigated" }\end{array}$ & 12 & $\begin{array}{l}\text { Commitment to risk prevention. } \\
\text { Example: "The institution encourages the participation } \\
\text { of every integrant in workplace risk prevention". }\end{array}$ & 2 \\
\hline $\begin{array}{l}\text { Responsibilities of the designer. } \\
\text { Example: "The selection of materials in the designing stage } \\
\text { has an influence on the number of workplace risks". }\end{array}$ & 4 & $\begin{array}{l}\text { Dissemination of preventive guidelines. } \\
\text { Example: "Guidelines for workplace risk prevention } \\
\text { are available to all members of the institution". }\end{array}$ & 2 \\
\hline $\begin{array}{l}\text { Responsibilities of the adjudicator. } \\
\text { Example: "The risk prevention measures included by the } \\
\text { contractor in his estimate should be considered as criteria } \\
\text { of technical solvency in tenders for the work". }\end{array}$ & 4 & $\begin{array}{l}\text { Ongoing preventive actions. } \\
\text { Example: "The institution continues to monitor the } \\
\text { performance of the contractors in risk prevention". }\end{array}$ & 4 \\
\hline $\begin{array}{l}\text { Responsibilities of the supervisors. } \\
\text { Example: "The supervisors must have knowledge of the } \\
\text { standards for workplace risk prevention applicable to } \\
\text { the construction". }\end{array}$ & 3 & $\begin{array}{l}\text { Organization for prevention. } \\
\text { Example: “There is a member responsible for risk } \\
\text { prevention in the institution". }\end{array}$ & 2 \\
\hline Number of items & 23 & Number of items & 10 \\
\hline
\end{tabular}


Table 2 shows the sections included in this instrument of observation as well as the subsections contained in each section; in this table, for each section presented, there is an abbreviation in parentheses, which will be used in the presentation of results.

For greater clarity, as an example of the above, the seven items included in the section for sanitation facilities are as follows:

Sanitation Facilities:

Table 2. Structure of the instrument of observation in the construction sites.

\begin{tabular}{|c|c|}
\hline Sections & Subsections \\
\hline \multirow{3}{*}{ General disposition of the work site (Work site), 27 items. } & Organization and management of safety \\
\hline & Disposition of the worksite \\
\hline & Order and cleanliness of the worksite \\
\hline \multirow{13}{*}{ Specific construction jobs (Jobs), 141 items. } & Excavations \\
\hline & Masonry and walls \\
\hline & Demolitions \\
\hline & Finishing on walls, ceilings and floors \\
\hline & Welding \\
\hline & Cutting with oxyacetylene \\
\hline & Work at height \\
\hline & Electric works and air-conditioning \\
\hline & Shoring \\
\hline & Reinforcing steel work \\
\hline & Concrete work \\
\hline & Painting \\
\hline & Aluminum and glass work \\
\hline \multirow{3}{*}{ Conditions and use of machinery and equipment (Machinery), 63 items. } & Heavy machinery and light equipment \\
\hline & Scaffolding and ladders \\
\hline & Air compressors \\
\hline \multirow{5}{*}{ Conditions, management and use of tools (Tools), 42 items. } & General usage \\
\hline & Hand tools \\
\hline & Electric tools \\
\hline & Cutting tools \\
\hline & Pneumatic tools \\
\hline \multirow{3}{*}{ Management and disposition of materials (Materials), 15 items. } & General topics \\
\hline & Manual load \\
\hline & Mechanical load \\
\hline \multirow{8}{*}{ Personal protective equipment (PPE), 81 items. } & Head \\
\hline & Eyes and face \\
\hline & Ear \\
\hline & Respiratory system \\
\hline & Hand \\
\hline & Trunk \\
\hline & Lower limbs \\
\hline & Others \\
\hline \multirow{3}{*}{ Hygiene services (Hygiene), 7 items. } & Sanitary services \\
\hline & Dining area \\
\hline & Garbage management \\
\hline
\end{tabular}


1) Toilets are provided (mention how many).

2) Wash-hand basins are provided (mention how many).

3) Showers are provided (mention how many).

4) Soap is provided in the sanitation facilities.

Dining area:

5) A dining-area is provided on the work site; this area is sufficiently clean.

6) Tables and benches are adequate and sufficient for the number of workers.

Garbage management:

7) Any garbage generated on the worksite is collected and removed from the worksite periodically.

Observations were carried out in the worksites over a period of 11 months. The analysis of the data obtained from the observation instrument in the worksites consisted in calculating the percentage of compliance (PC) of each section of the instrument; the PC was calculated as the percentage of the number of regulations complied (RC), with respect to the number of applicable regulations (AR) during the observation visits, according to Equation (1):

$$
P C=\frac{R C}{A R}(100)
$$

A similar calculation was performed on each project to obtain the percentage of global compliance (PGC) with the applicable regulations; the PGC was calculated as percentage of the sum of regulations complied with in the project, with respect to the sum of applicable regulations during the observation visits (Equation (2)).

$$
P G C=\frac{\Sigma R C}{\Sigma A R}(100)
$$

The average of the PC was calculated for each section of the instrument; this measure of central tendency was used since the data were in ratio scale, representing the number of behaviors observed.

\section{Results}

\subsection{Attitudes Assumed by Members of the Institution}

Table 3 shows the medians of the values obtained from the instrument which measured the attitude assumed by members of the institution, regarding the phenomenon of prevention. Columns 2, 3 and 4 correspond to the medians of the points obtained from the opinions of the people performing the three different functions in the institution (design, adjudication and supervision); columns 5 and 6 contain the values obtained from the opinions of the 18 people interviewed.

Also in Table 3, it is possible to observe that all the interviewees expressed their opinion on the general aspects of prevention, and on what they consider to be the responsibilities of their co-workers, as well as their own (the latter have been shaded in the table). One should remember that, in the scale used, 5 represents the best attitude and 1 the worst.

\subsection{Encouraging Values within the Institution}

Similarly, Table 4 shows the medians of the values obtained from the perception of members of the institution as to how this entity encourages values relating to prevention.

\subsection{Evaluation of the Specific Actions That Members of the Institution Must Carry Out}

For each of the functions, the results of the evaluation of specific preventive actions that must be carried out within the institution are as follows:

\subsubsection{Designer}

- No risk prevention studies are carried out for the projects which could set the standards for the stages of adjudication and execution. It is important to clarify that this document is different from, and does not substitute, the detailed prevention plan that the contractor who wins the tendering process must develop for the execution of the work. 
Table 3. Medians of the points obtained for attitudes assumed by the people performing the different functions in the institution.

\begin{tabular}{cccccc}
\hline \multirow{2}{*}{ Components } & Designer & Adjudicator & Supervisors & \multicolumn{2}{c}{ Total } \\
\cline { 5 - 6 } & & & & Median & Interquartile range \\
\hline General aspects of prevention & 4.50 & 4.00 & 4.00 & 4.00 & 0.25 \\
Responsibilities of the designer & 3.00 & 5.00 & 4.00 & 4.00 & 1.00 \\
Responsibilities of the adjudicator & 4.00 & 4.00 & 4.00 & 4.00 & 0.00 \\
Responsibilities of the supervisors & 5.00 & 5.00 & 4.00 & 5.00 & 0.50 \\
\hline
\end{tabular}

Table 4. Medians of points obtained in relation to the encouragement of values in the area of prevention within the institution.

\begin{tabular}{cccccc}
\hline Values and policies & Designer & Adjudicator & Supervisors & \multicolumn{2}{c}{ Total } \\
\cline { 5 - 6 } & & & & Median & Interquartile range \\
\hline Commitment to risk prevention & 5.00 & 4.00 & 4.00 & 4.00 & 0.50 \\
Dissemination of guidelines for prevention & 5.00 & 4.00 & 4.00 & 4.00 & 0.50 \\
Ongoing preventive actions & 5.00 & 3.00 & 3.00 & 3.00 & 1.00 \\
Organization for prevention & 5.00 & 3.00 & 3.00 & 3.00 & 1.00 \\
\hline
\end{tabular}

- In the design stage, the risks associated with the execution of specific tasks are not identified as they should be, in order to manufacture the different constructive elements.

- The plans do not include graphic or textual information (figures, notes, criteria) indicating to the constructor how to eliminate or mitigate health and safety risks associated with the different work areas.

- In general, the design addresses only the requirements of the stage relating to operation of spaces (How should the building be constructed in order to be used adequately?) and does not address the stage pertaining to execution of the work (How to carry out the work as safely as possible?).

- The design team does not consult the normative standards of workplace safety or recommendations of the STPS. The task of risk prevention is entirely attributed to those responsible for the execution stage.

\subsubsection{Adjudicator}

- The curriculum required from a contractor in order to participate in the tendering process does not include information regarding his capacity or experience in prevention.

- In the evaluation stage of the tender package containing the technical proposal, the experience of the constructor in the area of prevention is not analyzed.

- The constructors participating in the tendering process are asked to sign a document, included in the list of requirements, in which they promise to comply with the content regarding safety and hygiene in the workplace.

- After the adjudication of the work, the obligation to comply with the requirements included in the aforementioned document is formalized in a clause within the public work contract and an annex.

- The main points included in this annex of safety and hygiene are the following: obligation to comply with the normative standards applicable to safety and health, organization of a commission for hygiene and safety in the worksite, use of personal protective equipment, verification of the condition of tools and equipment, use of warning signs, organization and order in the worksite, and preventive measures applicable to each job, with special emphasis given to working at height and those requiring special devices such as: scaffolding, ladders, hand-rails, platforms, etc.

- During the construction work, the institution does not gather information regarding the performance of the constructors in the area of prevention. 
- The adjudicator recognizes that it would be useful to have access to statistics which would facilitate an evaluation of the technical competence of the contractors based on behavior observed during the development of projects previously adjudicated and executed.

\subsubsection{Supervisors}

- During the execution of the construction work, the supervisors do not consult official normative standards for prevention, and use only the annex on safety and hygiene mentioned above, as their reference for preventive measures.

- Approximately half of the supervisors manifested that they monitor compliance with all the points included in the annex; while a fifth of all supervisors declared that they take no action whatsoever in the area of prevention, preferring to concentrate on compliance with the traditional parameters of performance in the execution of the work (time, cost and quality).

- Among the supervisors who admitted monitoring compliance only with the annex, approximately half reported that, when faced with situations of risk in the workplace, they make verbal requests to the contractor; while the other half make requests by means of the worksite log book.

- In the case of an accident, half of the supervisors said that it is not their attribution or responsibility to investigate the causes; and almost three quarters affirmed that they do not report it to the institution. In fact, no standardized procedure has been established in the institution to make this kind of report.

- Almost every supervisor commented that no campaigns were ever carried out in the work site with the aim of making the workers aware of the importance of prevention.

- Two thirds of the supervisors manifested that the topic of prevention is not discussed in the meetings routinely held with the contractors.

- All the supervisors said that, during the time they have been working for the institution, no training programs or promotional campaigns relating to safety in the workplace have been offered to the personnel of supervision.

- Two thirds of the supervisors commented that for the assignment of the works, their knowledge and experience in the area of prevention are not among the criteria taken into consideration.

\subsection{Observation of Project Execution}

Thirteen projects were observed in order to determine actions related to prevention carried out by the contractors. Table 5 presents the percentages of compliance (PC) with the safety requirements applicable in the jobs observed in the worksite, calculated according to Equation (1). The last column on the right shows the means of each section; while the last line of the table presents the percentage of global compliance of each project (PGC), calculated according to Equation (2). For all the values in the table the scale is from 0 to 100, in which 100 means that compliance with all applicable safety requirements was observed in every visit to a project, as in the case of the section for Tools in Project 5.

Table 5. Percentage of compliance with safety requirements in the worksites.

\begin{tabular}{|c|c|c|c|c|c|c|c|c|c|c|c|c|c|c|}
\hline \multirow{2}{*}{ Sections } & \multicolumn{13}{|c|}{ Projects } & \multirow{2}{*}{ Means } \\
\hline & 1 & 2 & 3 & 4 & 5 & 6 & 7 & 8 & 9 & 10 & 11 & 12 & 13 & \\
\hline Worksite & 24 & 52 & 54 & 50 & 29 & 12 & 68 & 44 & 31 & 35 & 36 & 46 & 73 & 43 \\
\hline Jobs & 55 & 55 & 55 & 63 & 58 & 40 & 47 & 54 & 52 & 51 & 58 & 61 & 59 & 54 \\
\hline Machinery & 55 & 69 & 56 & 54 & 33 & 54 & 60 & 53 & 49 & 49 & 53 & 60 & 65 & 55 \\
\hline Tools & 70 & 68 & 63 & 83 & 100 & 68 & 83 & 63 & 56 & 65 & 63 & 67 & 77 & 71 \\
\hline Materials & 73 & 70 & 92 & 75 & 83 & 83 & 42 & 71 & 87 & 73 & 73 & 77 & 69 & 74 \\
\hline PPE & 17 & 45 & 44 & 37 & 12 & 10 & 47 & 24 & 14 & 15 & 20 & 20 & 16 & 25 \\
\hline Hygiene & 50 & 75 & 50 & 17 & 17 & 17 & 17 & 33 & 50 & 50 & 33 & 71 & 71 & 42 \\
\hline Global & 45 & 59 & 54 & 55 & 41 & 40 & 54 & 45 & 39 & 39 & 45 & 48 & 50 & 48 \\
\hline
\end{tabular}




\section{Discussion}

Based on the points obtained, the individuals performing each of the three functions in the institution while this study was being carried out showed an acceptable attitude regarding the general aspects of prevention (values of 4.0 and 4.5, in a scale of 1 to 5). However, it is important to note that the designer and the adjudicator are of the same opinion, in that the main responsibilities for the area of prevention lie with the other two functions, and more specifically, with the supervisors, the latter arising from a rather old-fashioned, biased vision of the phenomenon of prevention in construction projects. The supervisors, on the other hand, assigned equal responsibility to the three functions, which corresponds to a more modern vision of the phenomenon.

In the normative document published in Mexico by the STPS, titled Guidelines for Safety and Health in the Workplace: Design and Contracting of Public Works [13], hereafter referred to as Guidelines for Design and Contracting, it is established that the government agencies "must have a policy of risk prevention in the workplace, in effect from the first stages of design and, more particularly, in the assignment and formulation of contractual requirements in order to generate adequate conditions for an optimal performance in safety and health in the work site". The same document also establishes that: "the causes of accidents arise from the most general surroundings to the most specific, while the most influential decisions originate from the conceptual stages (design) to the operatives”.

Similarly, in another normative document of the STPS, titled Safety Practices in the Construction Industry: Budget and Planning [14], hereafter referred to as Practices for Budget and Planning, it is established that "those responsible must identify if the design promotes activities in conflict with preventive measures for safety and health in the workplace... For example, installation plans must take into account fire prevention measures, for which some projects could require provisional work to ensure water supply and adequate access for protective equipment and emergency services”.

Regarding institutional values, based on the points obtained, the adjudicator and the supervisors were consistent in their opinions to the effect that the organizational efforts of the institution are insufficient, and that not enough preventive actions are taken (values of 3 in a scale of 1 to 5). On the other hand, the designer expressed a favorable vision in the four indicators considered for the values; most likely due to the fact that he has a more biased vision of prevention.

In relation to the specific actions that each member of the institution must carry out, it was quite obvious that no risk prevention studies are performed for the projects, during the stages prior to the execution (design and adjudication); as a result therefore, all the responsibility for prevention is left to the participants in the execution stage: contractor and supervisors.

The Design and Contracting Guidelines [13] establish that "the Workplace Safety and Health Study must be taken into consideration in the studies, projects and specifications required for the execution of public works". To complement the above, the document Budget and Planning Practices [14] states that: "The fundamental part of a Workplace Safety and Health Study is risk analysis, which must include: Environment, Effect of the work on the external environment, Simultaneous activities carried out in the work site and Simultaneous jobs carried out in the work site".

Additionally, in the work adjudication stage, no evidence was found of the institution analyzing the risk prevention capacity of contractors participating in the tender process. In relation to this, in the Design and Contracting Guidelines [13] it is stated that: "When taking into consideration the criteria of solvency and capacity of participants in the tender process, verification of their capacity to execute the requirements in the area of workplace safety and health must be included".

In Mexico, applicable normative standards do not require the contractors participating in the tender process to employ experts specifically trained in prevention. In contrast, in other countries of Latin America, such as Chile, the government does insist on this requirement, as can be appreciated in the following citation: "The contractor must show, on inscription, that their organization includes a staff of qualified professionals... The required expert in risk prevention...must comply with the classification requirements indicated in article No. 9...of the Ministry of Labor and Social Security" [15]. Since there is no legal requirement to employ a safety expert in Mexico, the decision to use specialized consultancy for risk prevention in the workplace is left to the criteria or free will of the contractor.

In the institution under study, once the work has been adjudicated, the only framework of reference used for prevention is a document with general safety recommendations which is annexed to the contract. However, in 
the Design and Contracting Guidelines [13], it is established that "with the antecedent of the Workplace Safety and Health Study, the company that has been awarded the contract must elaborate, as part of the requirements, a plan identifying in detail the risks and measures of prevention to be carried out during the execution of the work". In this case study, the institution does not carry out the study referred to in the planning and design stage, nor does it require the company to provide the safety plan mentioned above.

Besides this, no evidence was found of the accidents being registered or of any analyses of the causes, and the supervisors did not receive any training in this area. These three points (register, analysis and training) can be confirmed as indispensable to set in motion a process of improvement in construction organizations, since they will help to break the vicious circle of repeating the same unsafe behavior again and again.

With reference to the actions relating to prevention observed in the work sites, the percentages of compliance (PGC) with safety requirements, for the 13 projects, ranged between 39 and 59 (in a scale from 0 to 100); which can be considered extremely deficient. This is consistent with multiple observations presented in the sub-section dealing with the evaluation of specific actions which the institution should carry out in the area of risk prevention. This can be considered a consequence of not giving enough attention to prevention in the stages of design and adjudication.

The highest percentages of compliance were obtained for the sections: Conditions and use of machinery and equipment (Machinery), and for Management and disposition of materials (Materials), with percentages of compliance with safety requirements of 74 and 71 , respectively. The lowest qualification was for Personal protective equipment (PPE), with a percentage of compliance of 25.

It is interesting to note that the best qualifications were obtained for elements forming a part of the company's assets (machinery and materials), while the worst was obtained for the fundamental element of prevention, the worker. This could be interpreted from the perspective that the preventive actions in the sections with the two best qualifications were motivated by the desire to safeguard the patrimony of the companies, rather than protect the integrity of the workers. Figure 1 shows clearly the contrast in the percentages observed in each project, with respect to the three areas mentioned above.

\section{Conclusions}

The modus operandi of the institution corresponds to a biased vision in which the responsibility for risk prevention in the workplace is considered to lie exclusively with the participants in the execution stage of the projects: contractors and supervisors.

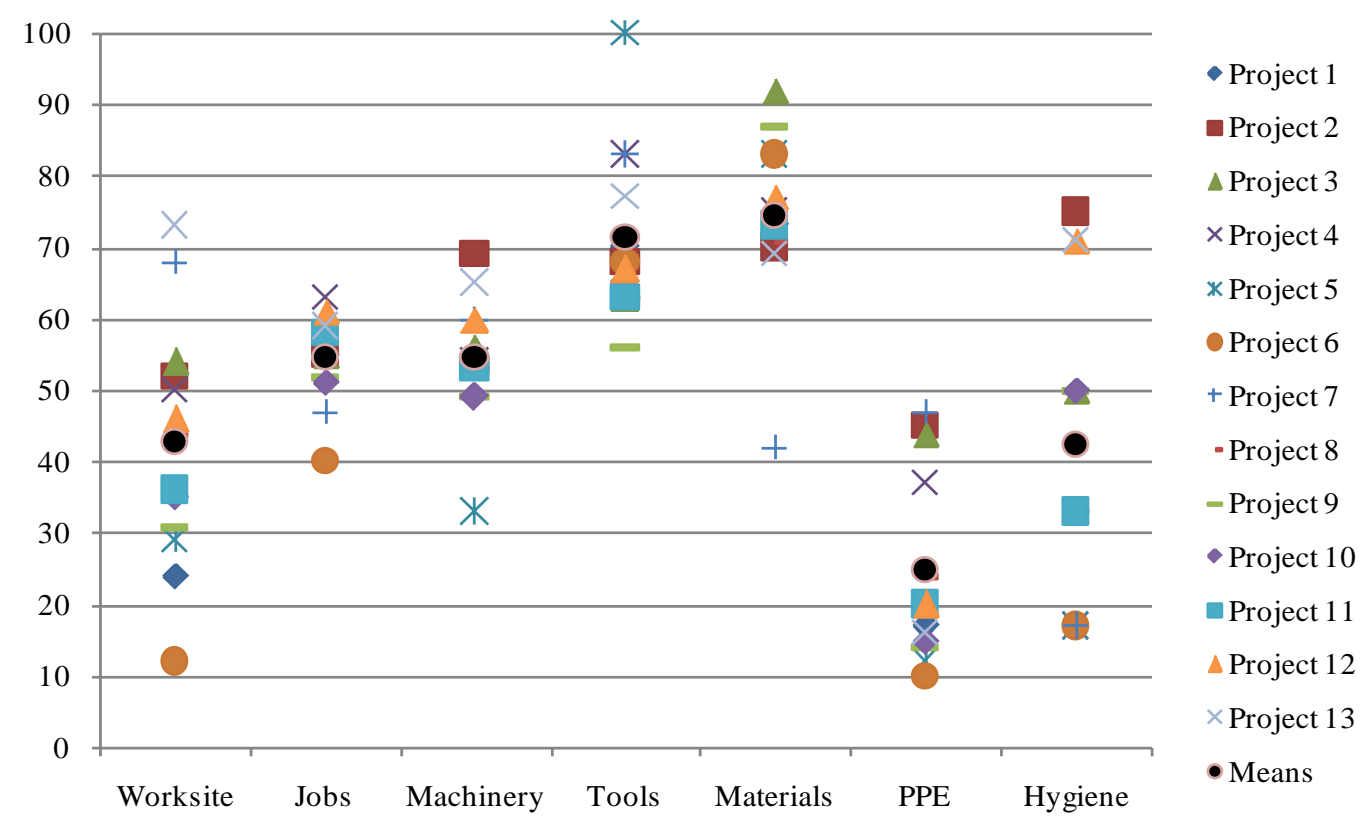

Figure 1. Graph of contrasts in the percentages of compliance with safety requirements in the 13 work sites observed. 
The experience and technical capacity of these two participants are not taken into consideration in order to assign the works to those who can guarantee the best results possible in the area of prevention.

In the institution, safety is not planned; the causes and circumstances of the accidents that occur are not analyzed in order to generate knowledge, and the personnel do not receive training in order to avoid their repetition.

In the institution, the recommendations established by the government agency responsible for regulating risk prevention in construction (STPS) are not duly observed.

The use of personal protective equipment in the workplace, which is the basic indicator of prevention, was seen to register the lowest degree of compliance; this would appear to be paradigmatic of the importance awarded to this responsibility by the institution and the contractors.

This work shows the first evidence that, in Mexico, the regulatory framework regarding risk prevention is not complied with, not even when the projects are managed by the government itself. From this we can conclude that in order to provide construction workers with adequate conditions of safety and hygiene, a profound change is required in the way both the government and businessmen interpret their obligation to comply with the rule of law and human rights.

\section{References}

[1] Rodríguez, S. (2010) La prevención de riesgos laborales en las obras públicas: logros y fracasos. Revista Jurídica de Castilla y León, 20, 127-193.

[2] INEGI (2013) Sistemas de cuentasnacionales de México. Instituo Nacional de Estadística y Geografía, Méxivo. http://www.inegi.org.mx/est/contenidos/proyectos/scn/

[3] CMIC (2013) Los retos de la infraestructura en México 2013-2018. Cámara Mexicana de la Industria de la Construcción, México.

[4] STPS (2011) Información sobre accidentes y enfermedades de trabajo nacional 2002-2011. Secretaría del Trabajo y Previsión Social, México. http://www.stps.gob.mx/bp/secciones/dgsst/estadisticas/Nacional\%202002-2011.pdf

[5] ISTAS (2014) Saludlaboral. Instituto Sindical de Trabajo, Ambiente y Salud, España. http://www.istas.net/web/index.asp?idpagina=1233

[6] ONU (1948) Declaración Universal de los Derechos Humanos. Asamblea General de las Naciones Unidas, Nueva York.

[7] OIT (1981) Convenio 155 sobre Seguridad y Salud de los Trabajadores. Organización Internacional del Trabajo, Ginebra.

[8] Congreso de la Unión (2014) ConstituciónPolítica de los EstadosUnidosMexicanos. Secretaría de Gobernación, México.

[9] Solís, R. and Franco, R. (2014) Construction Worker’s Perceptions of Safety Practices: A Case Study in Mexico. Journal of Building Construction and Planning Research, 2, 1-11. http://dx.doi.org/10.4236/jbcpr.2014.21001

[10] Solís, R. and Arcudia, C. (2013) Construction-Related Accidents in the Yucatan Peninsula, Mexico. Journal of Constructed Facilities, ASCE, 27, 155-162. http://dx.doi.org/10.1061/(ASCE)CF.1943-5509.0000300

[11] STPS (2011) NOM-031-STPS-2011, Construcción - Condiciones de seguridad y salud en el trabajo. Secretaríadel Trabajo y Previsión Social, México.

[12] STPS (2009) Guíapara la Evaluación del Cumplimiento de la Normatividad en Seguridad y Salud en el Trabajo. Programa de Autogestión en Seguridad y Salud en el Trabajo, Secretaría del Trabajo y Previsión Social, México.

[13] STPS (2010) Prácticasseguras en la industria de la construccion. Lineamientos de seguridad y salud en el trabajo en el diseño y contratación de obraspublicas (LC-01). Secretaría del Trabajo y Previsión Social, México. http://www.stps.gob.mx/bp/secciones/dgsst/publicaciones/prac_seg/construccion/LC-01.pdf

[14] STPS (2010) Prácticasseguras en la industria de la construccion. Presupuesto y planeación (PA-04). Secretaría del Trabajo y Previsión Social, México. http://www.stps.gob.mx/bp/secciones/dgsst/publicaciones/prac_seg/construccion/PA-04.pdf

[15] MOP (2010) Decreto 75 Ministerio de Obras Públicas, recopilación oficial de la Contraloría General de la República. Ministerior de Obras Públicas, Chile. 
Scientific Research Publishing (SCIRP) is one of the largest Open Access journal publishers. It is currently publishing more than 200 open access, online, peer-reviewed journals covering a wide range of academic disciplines. SCIRP serves the worldwide academic communities and contributes to the progress and application of science with its publication.

Other selected journals from SCIRP are listed as below. Submit your manuscript to us via either submit@scirp.org or Online Submission Portal.
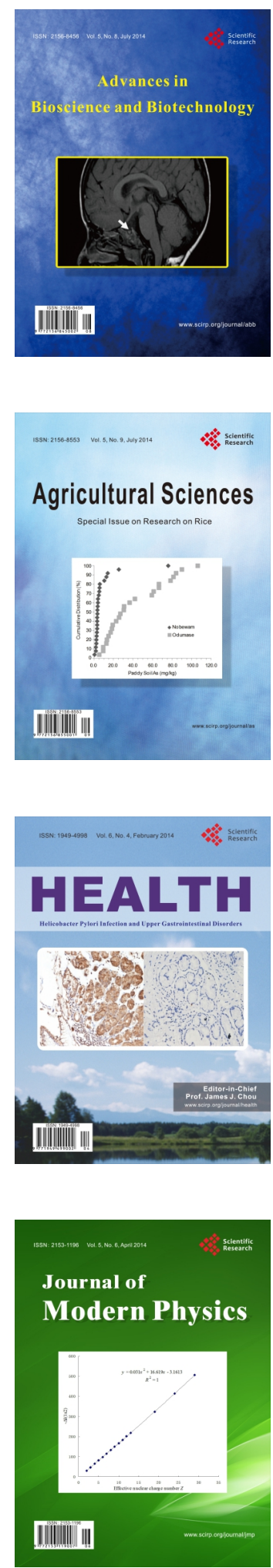
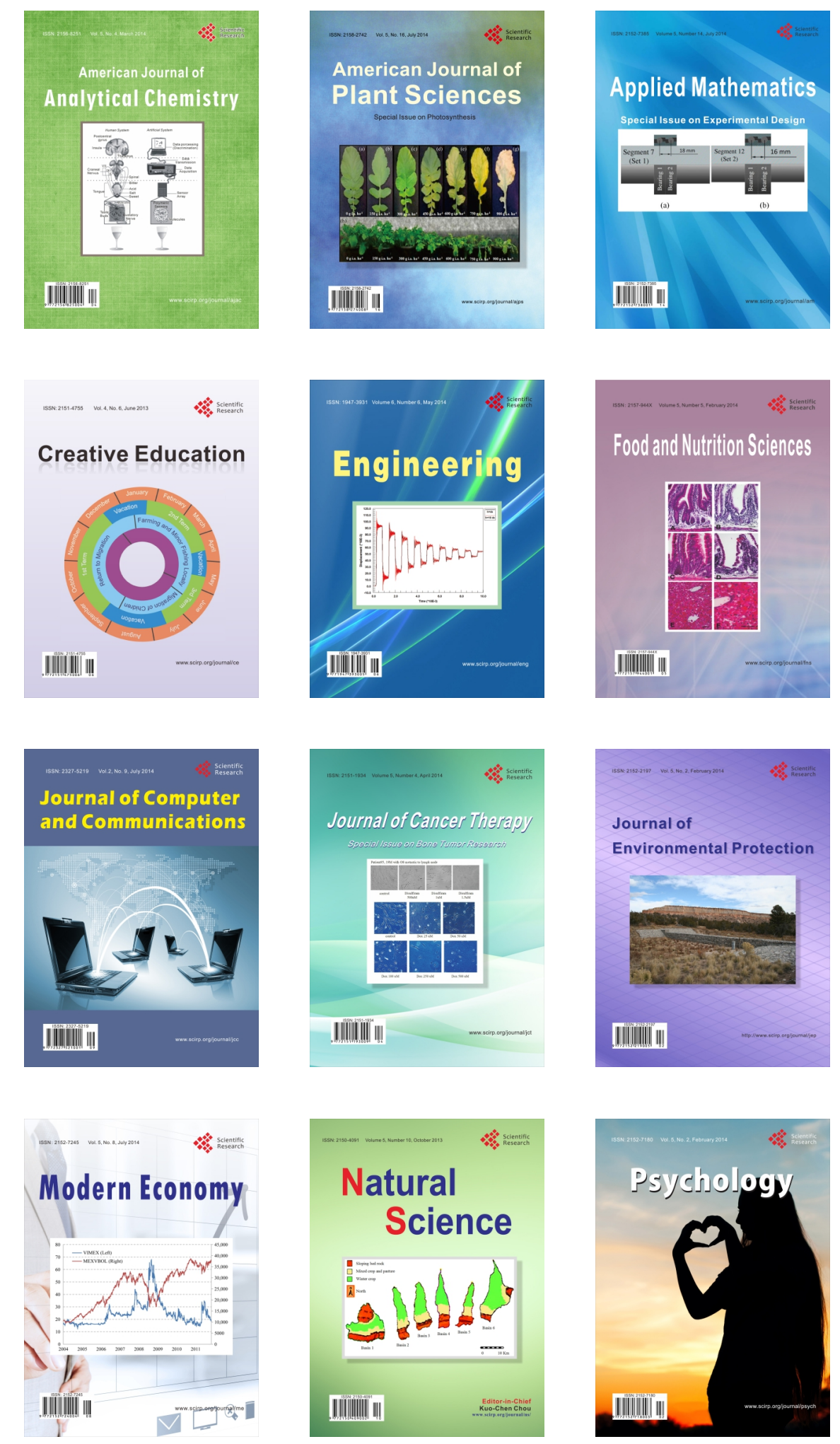